\title{
スペックルフォトグラフィー法による 燒結高硬度材料のヤング率の測定*
}

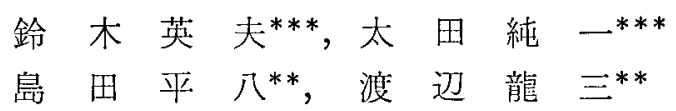

Hideo Suzuki, Jun-ichi Ohta, Heihachi Shimada, and Ryuzo Watanabe: Determination of Young's Moduli of Some Sintered Hard Materials by Speckle Photography.

Young's moduli of some sintered hard materials (WC-CO alloys and hot pressed $\mathrm{Si}_{3} \mathrm{~N}_{4}$ ) were measured by Speckle Photography. The advantage of using this strain measurement method was emphasized for the determination of Young's moduli in these hard materials.

The results of this study are summerized as follows:

(1) Young's moduli of the sintered hard materials in this study were found to be uniform along specimen axes under static compression.

(2) It was confirmed that Young's modulus of WC-Co alloys decreases with the increase in Co content, as has been reported before.

(3) In hot pressed $\mathrm{Si}_{3} \mathrm{~N}_{4}$, Young's modulus along the axis pallarel to the hot pressing direction was found to be larger than that vertical to the hot pressing direction by seven to ten percent.

(Received January 6, 1986)

I 序論

著者らは前報に就いて，スペックルフォトグラフィー 法による多孔質銅燒結体のヤング率の測定結果について 報告した²。それによれば，本法は非接触型で感度・精 度とむによく，しかもゲージ長が十分に短いひずみ測定 法であり，ヤング率の局所的な分布を測定する方法とし ては今のところ最す適した方法のひとつであることがわ 加た.

そこで，とのスペックルフォトグラフィー法を用いて 烧結高硬度材料，すなわち，WC-Co 合金およびホット プレス窒化ケイ素 $\left(\mathrm{Si}_{3} \mathrm{~N}_{4}\right)$ のヤング率の測定を試みた. なお，ホットプレス焼結体については，従来報告されて いるヤング率の異方性 ${ }^{2,3}$ ，あるいは，試料内におりるひ ずみの不均一の有無などについても検討した。

\section{【実 験 方 法}

ひずみ測定に供した試料は，WC-Co 合金とホットプ レス $\mathrm{Si}_{3} \mathrm{~N}_{4}$ である，WC-Co 合金は，WC 粉末（平均粒 径 $4.5 \mu \mathrm{m})$ と Co 粉末 $(5 \mu \mathrm{m})$ をボールミルで $345.6 \mathrm{ks}$ 混合し, Co 含有量 $5.5 \sim 25 \mathrm{wt} \%$ 上して金型成形したも のを 1633 1703 K で 2.4 ks 真空中で焼結した. 焼結後 所定の寸法に研磨し，さらに研磨時の残留応力を除去す
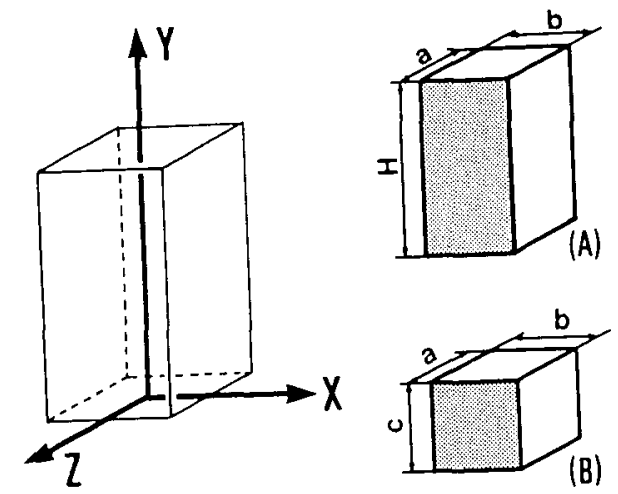

Fig. 1 Specimen geometries of WC-Co alloys, hot pressed $\alpha-\mathrm{Si}_{3} \mathrm{~N}_{4}$, and $\beta-\mathrm{Si}_{3} \mathrm{~N}_{4}$.

$\mathrm{z}$ axis shows the hot pressing direction.

(A) Long specimen (B) Short specimen Sizes of the specimen are given in Table 1.

るために水素中で $1073 \mathrm{~K}, 300 \mathrm{~s}$ アニールにした.一方, ホ ットプレス $\mathrm{Si}_{3} \mathrm{~N}_{4}$ は市販のもので, Fig. 1 のZ軸に平行 な力向に $2073 \mathrm{~K} 19.6 \mathrm{MPa}$ の条件でホットプレス成形

* 昭和60年11月本協会秋季大会江て発表，昭和61年 1 月 6 日 受理.

***東北大学工学部金属加工学科, $=980$ 仙台市荒巻字青葉.

*** 東北大学大学院, 9980 仙台市荒巻字青葉. 
Table 1 Specimens used for Speckle Photography.

\begin{tabular}{rccc}
\hline & $\mathrm{a}$ & $\mathrm{b}$ & $\mathrm{H}$ \\
\hline $\mathrm{WC}-5.5 \mathrm{wt} \% \mathrm{Co}$ & 8.00 & 6.96 & 17.10 \\
10 & 7.97 & 6.91 & 17.09 \\
16 & 8.00 & 7.01 & 17.09 \\
20 & 8.00 & 6.95 & 17.10 \\
25 & 7.99 & 6.97 & 17.09 \\
\hline$[1] \alpha-\mathrm{Si}_{3} \mathrm{~N}_{4}$ (A) & 8.62 & 8.64 & 16.61 \\
(B) & & & $(\mathrm{c}=7.86)$ \\
{$[2] \beta-\mathrm{Si}_{3} \mathrm{~N}_{4}$ (A) } & 7.14 & 7.20 & 18.70 \\
(B) & & & $(\mathrm{c}=6.46)$ \\
\hline
\end{tabular}

$(\mathrm{mm})$
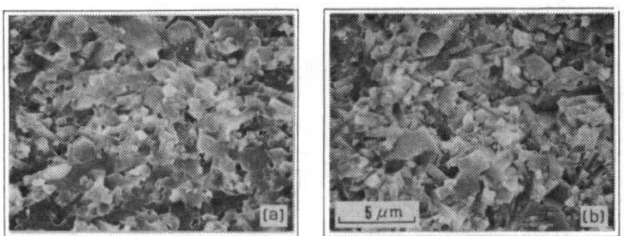

Photo. 1 SEM photographs of fracture surfaces of hot pressed $\mathrm{Si}_{3} \mathrm{~N}_{4}$ (a) $\alpha-\mathrm{Si}_{3} \mathrm{~N}_{4}$, (b) $\beta-\mathrm{Si}_{3} \mathrm{~N}_{4}$.

したあのである.それらの角柱状試料の寸法を Table 1 に示す. Table 1 中の $\mathrm{Si}_{3} \mathrm{~N}_{4}$ のうち [1] は $\alpha$ 型サイ アロンで高温強度の向上を期待したあの, [2] は $\beta$ 型 $\mathrm{Si}_{3} \mathrm{~N}_{4}$ で粒界の結晶化をはかったあのである。これらの 試料の抗折破断面を Photo. 1 (a), (b) に示す.

ひずみ測定は前報1) と同様に変位制御式の荷重装置を 用いて圧縮試験にて行った．なお，前報であ述べた通り 圧縮試験時には試料の端面効果（摩擦の影響）はないも のと考えた．測定時の温度は $293 \pm 1 \mathrm{~K}$ であった.

WC-Co 合金については Fig. 1(A) のY軸方向に荷 重を加える圧縮試験を行った。ホットプレス成形した $\mathrm{Si}_{3} \mathrm{~N}_{4}$ については，はじめにホットプレス方向に垂直方 向（Y軸方向）の圧縮試験を行い，次に 同一の試料を Fig. 1(B) のように切断してホットプレス方向に平行な 方向（ $\mathrm{Z}$ 軸方向）の圧縮試験を行った.

測定に用いた光学系は前報と全く同様であるが，撮影 倍率は $\mathrm{Si}_{3} \mathrm{~N}_{4}$ のホットプレス方向に平行な方向に压縮荷 重を加える場合には約 2 倍，その他の場合には等倍とし， 高分解能写真乾板に 2 重露光した. 干渉じまを再生する 時にはレーザー光のスポット径を $1 \mathrm{~mm}$ として pointby-point method により, 圧縮軸, すなわち試料側面 の中心線に沿った各点で試料の変位分布を求めた. 本法 では, レーザースポット内の平均的な変位量が干渉じま として得られるようになっているので, この場合のゲー ジ長は $\mathrm{Si}_{3} \mathrm{~N}_{4}$ のホットプレス方向に平行な方向（Z軸方 向）では約 $0.5 \mathrm{~mm}$ ，それ以外では約 $1 \mathrm{~mm}$ となった. ヤング率は応力とひずみから算出した.

\section{III 実 験 結 果}

WC-Co 合金試料に圧縮応力を加えた場合の変位分布 を，压縮軸方向に沿って求めた一例を Fig. 2 に示す. ここでは Co 含有量が $25 \mathrm{wt} \%$ の試料に圧縮応力 52.9 MPa を加えた時の結果を示した. Fig. 2で, 縌軸は圧縮 時の変位, 横軸は試料の下端面からの距離 $y$ を試料高さ $H$ で除して規格化した值である.つまり, 横軸の値 0 は 同図中の模式図の $\mathrm{A}$ 点を示し，乙れは圧縮試験時におけ る試料の下端面である. 同様に横軸の值 1 は上端面 $B$ 点 を示している，なお，圧縮試験時に試験装置などの弾性 変形により下端面A むいくらか剛体変位するが, Fig. 2 ではその剛体変位量を差し引き $\mathrm{A}$ 点上では変位が 0 にな るように描いてある.

これらの実験点を直線近似してみると, Co 含有量が $25 \mathrm{wt} \%$ の試料に限らずいずれの WC-Co 合金試料にお いてあ相関係数が0.99以上あったので, 变位分布曲線は 直線とみなすととができる. すなわち, 測定方向におい ては変形が一様であり,ひずみ分布の局所的な変化はな いととが確認された.

ヤング率は応力とひずみから算出した，応力は荷重を 試料断面積で除した值であり, 試料軸に沿って一様であ

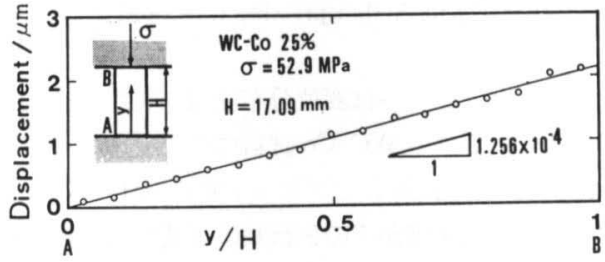

Fig. 2 An example of displacement distribution along specimen axis A-B of WC-Co alloy determined by Speckle Photography.

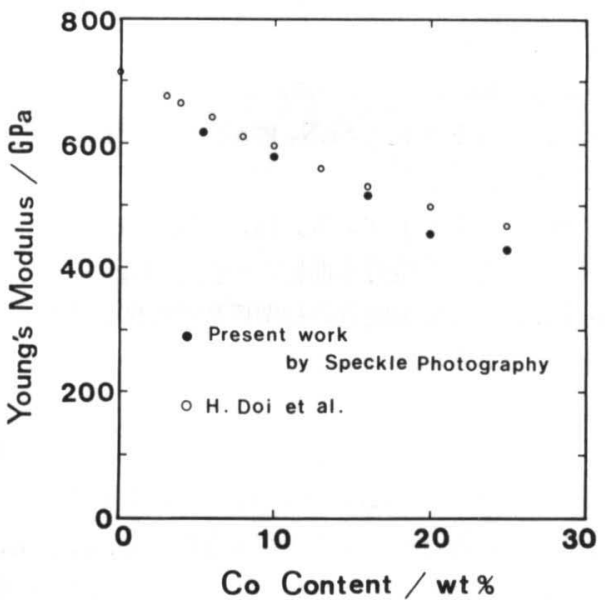

Fig. 3 Variation in Young's modulus of WC-Co alloys with Co content.

Experimental points were taken from present work and from literature (4). 


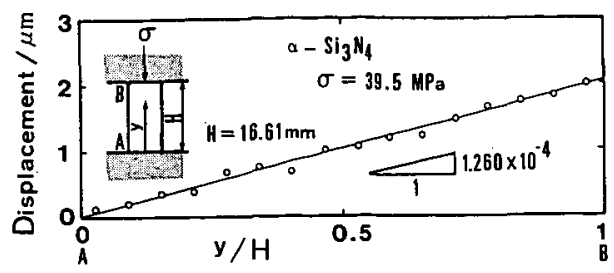

Fig. 4 An example of displacement distribution along specimen axis $\mathrm{A}-\mathrm{B}$ of hot pressed $\alpha-\mathrm{Si}_{3} \mathrm{~N}_{4}$ determined by Speckle Photography (vertical to the hot pressing direction).

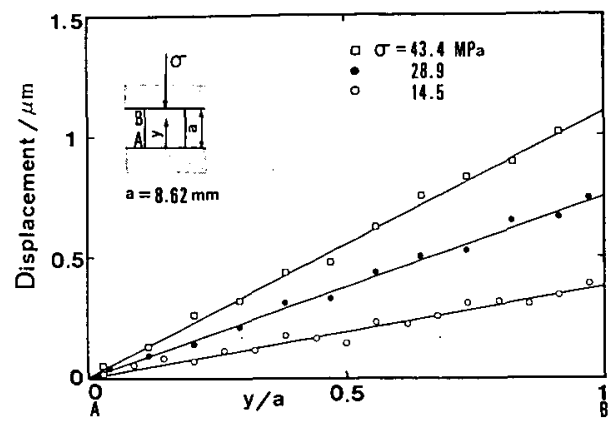

Fig. 5 Displacement distributions along specimen axis A-B of hot pressed $\alpha-\mathrm{Si}_{3} \mathrm{~N}_{4}$ deternined by Speckle Photography.

(parallel to the hot pressing direction)

ると仮定した．ひずみは变位分布曲線（実際は直線）の 勾配である. 5 つの WC-Co 試料についてヤング率を計 算し，Co 含有量に対してプロットすると Fig. 3 のよう になった。引用文献からの值はピエゾ式の高周波縦振動 法を用いて測定した結果4であり，Co 含有量が多くな るにつれてャング率が小さくなるという傾向は本実験で あ定性的に一致している.なお，いっぱん代引張や圧縮 などの静的方法によって求められるャング率は，動的方 法で得られるヤング率よりあ小さくなるととが知られて いるが5)，本結果にもその傾问がみられる。

次に，ポットプレス $\mathrm{Si}_{3} \mathrm{~N}_{4}$ について圧縮試験を行った 結果を示す.

$\alpha-\mathrm{Si}_{3} \mathrm{~N}_{4}$ のホットプレス方向に垂直な方向に玨縮応力 を加えた場合の変位分布曲線の一例を Fig. 4 亿示す.

Fig. 4 亿おいても実験点の相関係数は0.99以上であった ので，変位分布曲線は直線とみなすてとができる．この ことは圧縮応力の大きさを変えても同梯であった，一方， ホットプレス方向に平行な方向に玨縮応力を加えた場合 の変位分布曲楾は Fig. 5 のようになる. Fig. 5 であ変位 分布曲線は直線とみなすととができた．したがって，ホ ットプレス方向あるいはそれに垂直な力向の各々の軸方 向では，不均一な圧縮変形は起とらず一様に变形し，ひ ずみ分布の局所的な変化はないるのと思われる。乙れら の結果から，応力ひずみ曲線を描くと Fig. 6 の上うに

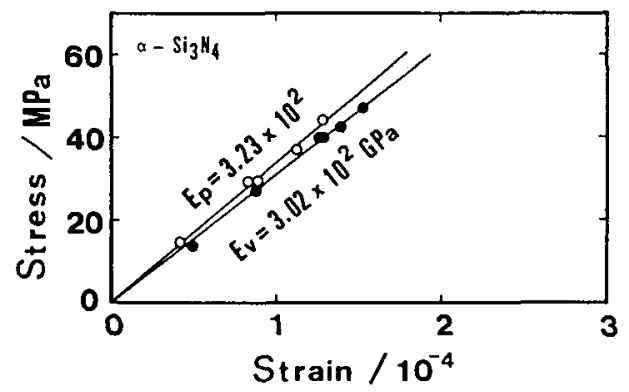

Fig. 6 Relation between stress and strain of hot pressed $\alpha-\mathrm{Si}_{3} \mathrm{~N}_{4}(-$; vertical to the hot pressing direction, $O$; parallel to the hot pressing direction)

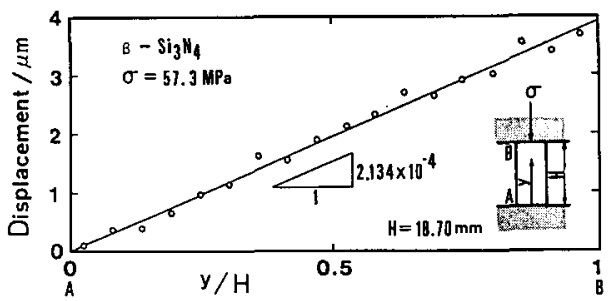

Fig. 7 An example of displacement distribution along specimen axis $\mathrm{A}-\mathrm{B}$ of hot pressed $\beta-\mathrm{Si}_{3} \mathrm{~N}_{4}$ determined by Speckle Photography. (vertical to the hot pressing direction)

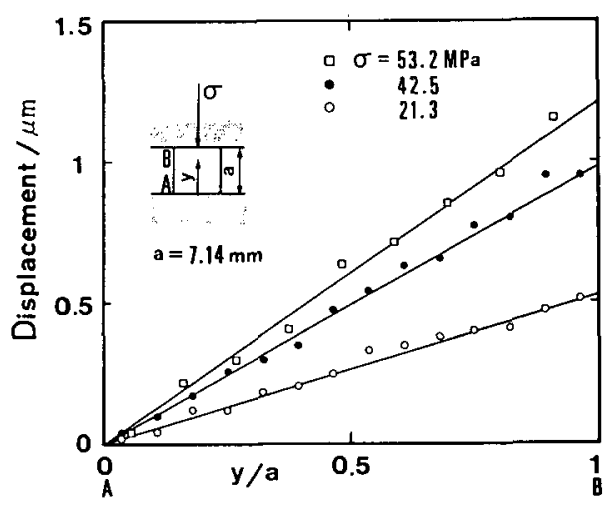

Fig. 8 Displacement distributions along specimen axis $\mathrm{A}-\mathrm{B}$ of hot pressed $\beta-\mathrm{Si}_{3} \mathrm{~N}_{4}$ determined by Speckle Photography.

(parallel to the hot pressing direction)

なる、ホットプレス方向に平行な方向に圧縮応力を加え た場合，応力一ひずみ曲線の勾配，すなわちヤング率は $3.23 \times 10^{2} \mathrm{GPa}$ ，またそ机垂直な力向では $3.02 \times 10^{2}$ $\mathrm{GPa}$ となり約 7\%の差がみられた。したがって，ヤン グ率にはホットプレス成形に起因すると思われる異方性 があるということがわかった。

Fig. 7,8,9 K $\beta-\mathrm{Si}_{3} \mathrm{~N}_{4}$ に対する圧縮試験の結果を 示す.乙れらの図から， $\alpha-\mathrm{Si}_{3} \mathrm{~N}_{4}$ の場合之同様に測定軸 方向に沿ったひずみ分布の局所的な変化はないがホホッ トプレス方向とそれ征垂直な方向のヤング率はそれぞれ 


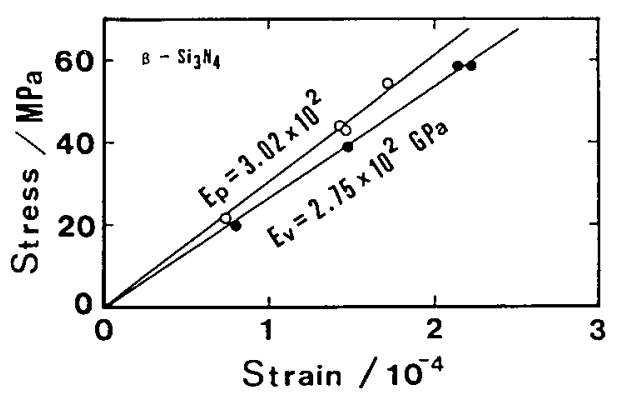

Fig. 9 Relation between stress and strain of hot pressed $-\mathrm{Si}_{3} \mathrm{~N}_{4}$. (O) vertical to the hot pressing direction, $O$; parallel to the hot pressing direction)

$3.02 \times 10^{2} \mathrm{GPa}, 2.75 \times 10^{2} \mathrm{GPa}$ 之約 $10 \%$ の差があり, $\beta-$ $\mathrm{Si}_{3} \mathrm{~N}_{4}$ においてもヤング率の異方性があるととがわかっ た.

これらの異方性については岩崎2 ${ }^{2}$, 若井, 松野, 津野3) らによっても報告されており，その原因として，ホット プレス成形に伴う結晶粒の方位配列，特定方位への粒成 長, さらに残留応力などが考えられている゙2.

なお， $\mathrm{Si}_{3} \mathrm{~N}_{4}$ 陚料のホットプレス方向に釷直な方向の ひとつである Fig. 1 のX軸方向に関しても圧繀試験を 行った．結果は前記した $\mathrm{Y}$ 軸方向の結果とほぼ同様であ った。したがって，本実験に用いた $\mathrm{Si}_{3} \mathrm{~N}_{4}$ はホットプレ ス方向軸（Z軸）に関して軸対称であるということが確 認された。

\section{IV 結 論}

スペックルフォトグラフィー法を用いて焼結高硬度材
料 (WC-Co 合金, ホットプレス $\mathrm{Si}_{3} \mathrm{~N}_{4}$ ) のヤング率を测 定した。 その結果, 本法は焼結高硬度材料のヤング率測 定に最適な方法のひとつであることがわかった。

（1）標準的な方法で作製した WC-Co 合金では，圧縮变 形時に压縮軸方向のひずみは均一であり，試料内にお けるヤング率の不均質はないととが確認された。

(2) WC-Co 合金では，従来報告されている Co 含有量 の増加に伴うヤング率の減少が, 本法によってあ再確 認さ机た。

(3) ホットプレス $\mathrm{Si}_{3} \mathrm{~N}_{4}$ では，ホットプレス方向に平行 な方向のヤング率はそれに垂直な方向のヤング率より あ7〜10\%大きいととがわかった．このととからホッ トプレス成形体におけるヤング率の異方性が明らかと なった。

おわりに，本研究をすすめるにあたって御協力いただ いた, 東北大学工学部金属加工学科, 川崎 亮博士およ び同学生，藤原一雅氏に，また， $\mathrm{Si}_{3} \mathrm{~N}_{4}$ 試料および破面 写真を御提供頂いた東芝タンガロイ侏福原幹夫博士に感 謝いたします。

\section{文献}

1) 渡辺，鈴木，島田：粉末および粉末治金，33 (1986)，69.

2) 岩崎: セラミックス, 12 (1977), 34.

3）若井, 松野, 津野: 第34回名古屋工業試験所, 所内研究発 表会前刷，(1983)，1.

4) H. Doi, Y. Fujiwara, K. Miyake, and Y. Oosawa: Metallurgical Transactions, 1 (1970), 1417.

5) 幾原, 上野, 吉永：案業協会誌, 93 (1985), 409.

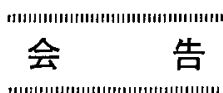

(412頁より続く)

2A 10 Direct HIP した窒化ケイ素の強度・破壊じん性 （豊田中研）。鷹取一雅，小林茂樹，和田重孝

2A11 窒化ケイ素材料の微細組織上破塤鞠性（日本特殊 陶業）。浦島和浩，多島 容，松尾康史

2A 12 空化ケイ素の破罗挙動之微構造観察（山形大工， 山形県工業技術センター*)。来次浩之・菅野幹男・佐 竹忠昭, 佐藤 啓*

$2 \mathrm{~A} 13 \mathrm{Si}_{3} \mathrm{~N}_{4}-\mathrm{SiC}$ 複合焼結体の機械的特性（三菱瓦斯化 学, 防衛大*) 伊崎寛正, 八京孝一, 安藤和弘, 川上殷 正, 新原皓一*

$2 \mathrm{~A} 14 \mathrm{Si}_{3} \mathrm{~N}_{4}-\mathrm{SiC}$ 系複合材のホットプレス（鹿児島大工） ○小含克彦, 福重安雄, 島田欣二

$2 \mathrm{~A} 15 \mathrm{Si}_{3} \mathrm{~N}_{4}$ 複合材料の特性 (東芝総研) 咪沢武之, 五 戸康弘, 井上 寛, 柘植章彦
$2 \mathrm{~A} 16 \mathrm{CVD}$ 法 $\mathrm{BN}-\mathrm{Si}_{3} \mathrm{~N}_{4}$ 複合セラミックス（新技術開 発事業団, 東北大*) 。中重博之, 松波幸男, 松田敏紹, 平并敏雄*

$2 \mathrm{~A} 17$ 機械加工可能な $\mathrm{SiC}$ の製造之特性（防衛大, 新 日曹化工*) 新原皓一, 山本 孝, 。竹本竜司, 菅沼 要, 奥村正利*

2A 18 高蜮性 $\mathrm{SiC} \cdot \mathrm{TiC}$ セラミックス燒結体（新日鉄第 一技研）。遠藤英宏, 種本 啓, 久保 紘

$2 \mathrm{~A} 19$ 金属粉末添加 $\mathrm{SiC}$ の強じん化（日立製作所，日 立研究所）後藤明弘, 三吉忠彦, 児玉弘則

$2 \mathrm{~A} 20 \mathrm{SiC}$ ウィスカー強化 $\mathrm{AIN}$ 焼結体の破壊エネルギ 一（京都工織大）西田俊彦, 吺北晃司, 塩野剛司, 西 川友三

$2 \mathrm{~A} 21$ 炭素被覆 $\mathrm{SiC}$ ウィスカー $/ \mathrm{Al}_{2} \mathrm{O}_{3}$ 複合体の機械的 特性 (東北大工材研, 日産中研*) 安田英一, 田辺靖 博, 片野 靖*, 。浜崎景久, 木村脩七

(425頁へ続く) 